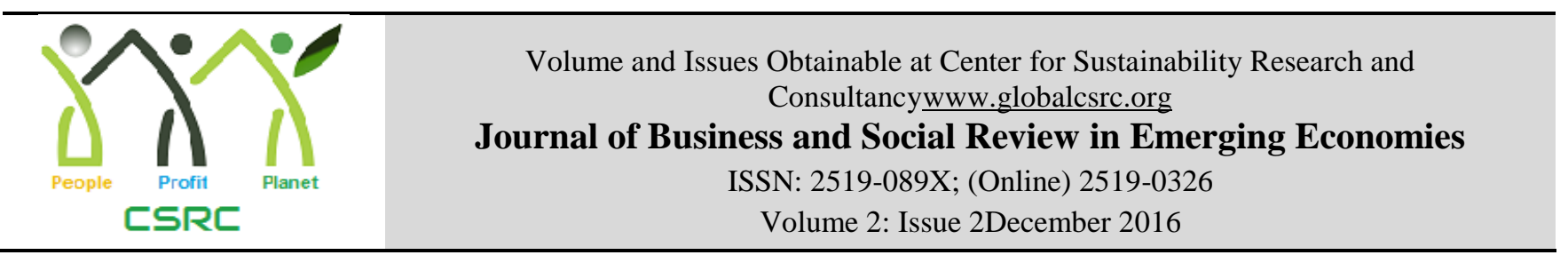

\title{
The Feasibility of Incorporating the Interactive Whiteboard in EFL Primary Classrooms
}

\author{
${ }^{1}$ Mohammad HusamAlhumsi, ${ }^{2}$ Dr. Ahmad AffendiShabdin \\ ${ }^{1}$ School of Education \& Modern Languages, College of Arts and Sciences, Universiti Utara Malaysia. \\ Email: husam 1001@yahoo.com, 01136554699 \\ ${ }^{2}$ School of Education \& Modern Languages, College of Arts and Sciences, Universiti Utara Malaysia. \\ Email: affendi@uum.edu.my, 0124645356
}

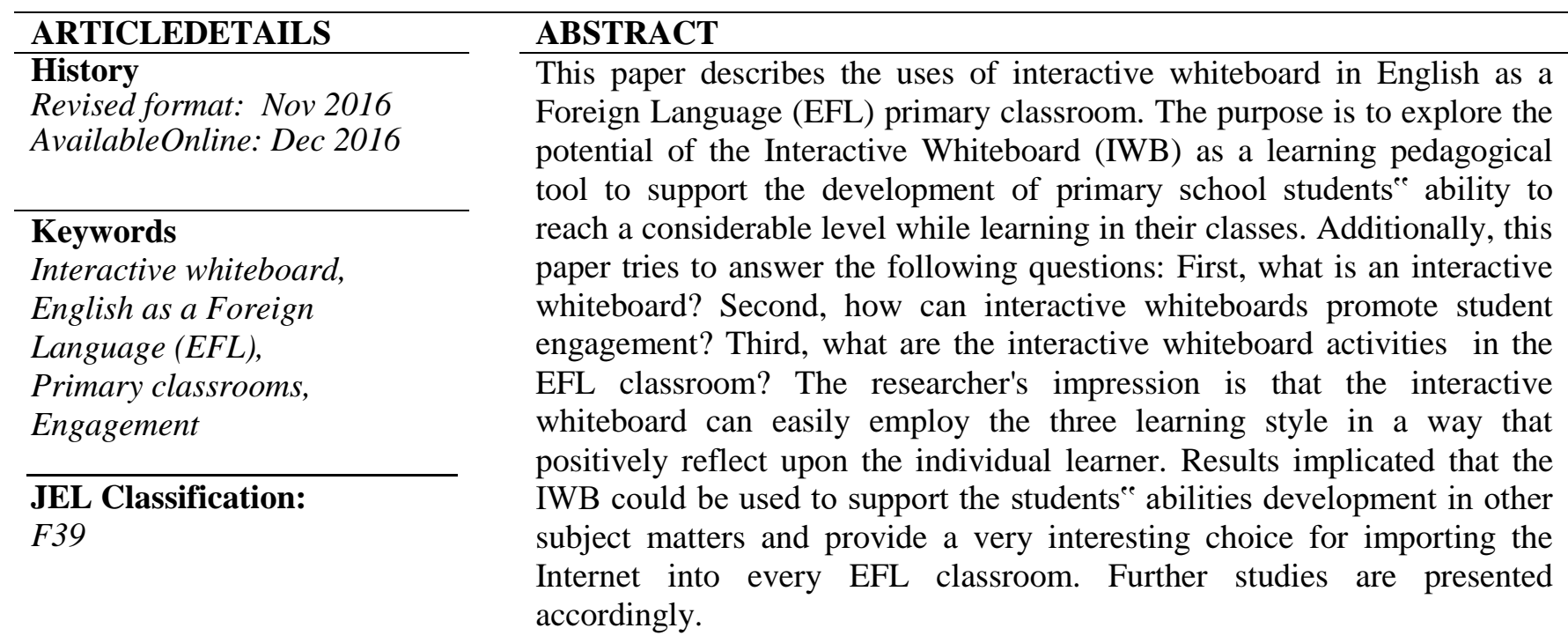

(C) 2016 The authors, under a Creative Commons AttributionNonCommercial 4.0

\section{Introduction}

Technology has changed our world. In the last few years, it has become more accessible to educators and students. Teachers should have the ability to use technology to boost their professional development. They should also have positive contact with their students regularly. The interactive whiteboard, considered one form of technology, proved to be an exciting and fun tool to incorporate. It has considerable effects on learning in several ways that involve upgrading the level of student engagement in a classroom, their motivation and raising enthusiasm for learning process (Bacon, 2011). It is important to note that interactive whiteboards help students in acquiring many different learning styles. They are used in a variety of learning environments that serve the teaching and learning process (Chapelle, 2003). Many elementary classrooms have used innovative technology with the purpose of *Corresponding author's email address: husam_1001@ yahoo.com

Recommended citation: Alhumsi, H. M., Shabdin, A. A. (2016). The Feasibility of Incorporating the Interactive Whiteboard in EFL Primary Classrooms. Journal of Business and Social Review in Emerging Economies, 2 (2) 135-142. DOI: https://doi.org/10.26710/jbsee.v2i2.30 
increasing reading skills and the achievement of the students (Englert, Zhao, Collings, \&Romig, 2005; Chambers, Slavin, \& Madden, 2008; Barone \& Wright, 2008; Cheung \&Slavin, 2011). Research proved that instructional technology, interactive whiteboard (IWB), for example, that evaluates student performance boosts phonics and decoding skills, being considered as major literacy skills (Lenhard, Baier, Endlich, Schneider, \& Hoffmann, 2011; Geske\&Ozola, 2009; Kendeou, van den Broek, White, \& Lynch, 2009). Thus, IWB can facilitate segmenting the sounds of the language.

To master literacy skills in modern world, students must have certain abilities such as using the Internet to access information, manipulating interactive technologies and streaming videos. They must be able to access information aswell as process what they read so that they can be successful in completing different tasks and functions (Belal, 2011; Barrow, Markman, \& Rouse, 2009;). According to Ertmer (2005), most educators and parents considered technology to be an integral part that provides a highquality standard in education. The intent of public school choice is to providing several learning environments may boost educators' creativity that reflects the intent of public school in improving the outcomes of students" achievement (DOE, 2005). Burnett (2010) asserted that instructors can facilitate this development through the use of technology in order that students can master new literacy skills in modern times.

\section{Research Questions}

This paper addressed the following research questions: First, what is an interactive whiteboard? Second, how can interactive whiteboards boost student engagement? Finally, what are the interactive whiteboard activities in the EFL classroom?

\section{Literature Review}

In order to answer the research questions, the researcher reviews literature regarding the use of interactive whiteboard and its effect on studentsee engagement. This chapter includes the definition of interactive whiteboard, the effect of IWB on studentse engagement, and the activities of the interactive whiteboard in the EFL classroom. It also provides a detailed description of the Incorporating the Interactive Whiteboard in Classrooms.

\subsection{What is an Interactive Whiteboard?}

An Interactive White Board is a pedagogical tool that takes the form of touch-sensitive screen. This screen works in combination with a computer and a projector. The images of the computer are shown on the board through a digital projector in a way that the instructor can display and manipulate figures and images. Controlling software from the computer and from the board can be done by users. Users can also add notations. They can emphasize the images via using a pen and/or highlighter tool. Using one ${ }^{\text {ee }} \mathrm{s}$ finger as a mouse, the teacher or student can directly run applications from the board. It is interesting to note that any notes or drawings can then be saved, printed out, and distributed to members of the group (Hall \& Higgins, 2005).

\subsection{How can Interactive Whiteboards Boost Engagement of the Students?}

The term ,engagement ${ }^{\text {ee }}$ in classroom involves social Learning environment. In this environment, most teachers are required to reinforce their beliefs and understandings concerning engagement in classrooms. This will make learning become an inherently social activity. It has been found that current theories in education are based on the notion of the social learner as well as the position of student engagement. These fundamental issues are considered as a major key of knowledge construction component. First, what brings the entire class together and concentrates their attention is the whole-class teaching and the interaction of teacher focused group. Second, constructivism depends on the learner in a way that he/she 
can select and transform information, construct hypotheses to make decisions and ultimately build meaning. Finally, learners who get active learning actively engage in the learning process through reading, writing, discussion and evaluation, instead of getting an absorbing passive instruction (AlSaleem, 2013).

Given the fact that student engagement is essential for learning represented a common thread between these three learning theories. Additionally, a growing body of international research proves the fact that interactive whiteboards boost the engagement of students (Beeland, 2002; Allen, 2010; Bacon, 2011). Using digital resources do not hamper dynamic interaction with the entire class; teachers can provide computer-based learning without separating students and encourage student in high level of interaction. Interactive whiteboards promote interaction among the teachers, students, and the learning materials. They enrich learning through technology in a way that offers a large work space with resources of multimedia (Reed, 2001). A teacher and a student can have the chance of interaction with the Interactive whiteboard before the class and the engagement include the rest of the students. Research proves that the function of the interactive whiteboard with its software allows for classroom activities developments that help in engaging more students in learning. Consequently, they encourage more participation, major focus, and required interaction which in turn leads to the improvement of student learning outcomes (AlSaleem, 2013).

\subsection{Activities of the Interactive Whiteboard in the EFL Classroom}

An Interactive whiteboard encourages the process of teaching of foreign languages in three major ways: First, it encourages conversation and interaction in the classroom. Second, it provides assistance with the presentation of new cultural and linguistic components. Third, it supports the oral skills.

\subsubsection{Activities that Support Conversation and Interaction with Students}

Based on the name of the interactive whiteboard, it involves interaction. In this new form of technology, the user can navigate from the board; he does not need to continually go back to the computer and result in turning his back to the class each time. The instructor is able to spend time focusing on the learning process of the student rather than focusing on the technology itself. This is crucial when using interactive whiteboards to teach. It is also crucial in the foreign language (EFL) classroom. A large number of foreign language teachers realize how difficult to have a relaxed conversation in the target language with the students. The Interactive whiteboard can facilitate particular types of conversations in a way that all individuals of the classroom may focus on the same issue at the same time (Al-Saleem, 2013).

The advantage of the interactive whiteboard is to enhance conversation. For example, the teacher can concentrate on the student's language production rather than technical issues. When he/she is navigating from item to different item, students are faced and interacted with their teacher. It has another advantage that is encouraging communication used in relation with a wireless keyboard. The teacher can interact with his/her students, practicing reading a text or having a conversation, for example. The conversation may develop smoothly through typing a new word onto the board to create the required conversation and the students do not have to write the word instantly (Al-Saleem, 2013). As a result, using images may provide best assistance in creating such conversation.

\subsubsection{Activities that Encourage the Presentation of New Linguistic and Cultural Components}

One of the essential uses of the interactive whiteboard is its assistance in presenting new linguistic and cultural components. As usual, a teacher can prepare a lesson in a Notebook file or Word Document. Then, the features of the Interactive whiteboard are able to be used in favor to his/her advantage. The instructor can use the Interactive whiteboard in various tasks such as overwriting, underlining, 
highlighting or circling the components that he/she likes to emphasize. Since the document is well typed, students can read it easily and simply. Furthermore, this document can be saved showed at any time in the future (Al-Saleem, 2013).

Additionally, the characteristics of the interactive whiteboard can make a big difference. For instance, it provides substantial aid when presenting authentic documents such as web sites. These sites enable the instructor to browse the document at length instead of remaining at a very simple level of presentation. In research, there are studies suggested the positive impact of authentic documents in language learning (Bacon, 2011; Allen, 2010). Using the interactive whiteboard, the educator can not only simply project a website, but he/she can also overwrite it to emphasize specific linguistic and cultural components through the process of navigation of the site with the use of one ${ }^{\text {ee }}$ s finger driven on the large screen.

\subsubsection{Activities that Encourage Oral Skills}

Pennington (1996) noted that the computer can sometimes have a power in encouraging that kind of anti-social behavior that leads to the work in isolation from others. This is a common criticism for using a computer. It is specifically relevant to the foreign language teacher. It is supposed for EFL teachers to interact with the class as much as possible. Materials should be presented via educational websites. When presented to the whole class, oral interaction can be enhanced by a web document displayed to the whole class. In this stage, opinions, ideas, and thoughts can be exchanged. This will gain more benefits if the students navigate the large screen instead of their teacher. The other students may guide each other. The teacher has to give directions in the target language when needed. As proposed for group activities that use the computer (Abraham \&Liou, 1991; Chapelle, 2003), students are encouraged and brought together in a communicative feature by incorporating the interactive whiteboard.

Given the projects on the large screen, students can present and have the opportunity of speaking with their other classmates. Without having to worry about the mouse, this let them have the ability to converse with each other. Images such as pictures and provided text are displayed immediately with a simple touch of a finger. In this way, the oral production of the target language is placed in the appropriate situation (Al-Saleem, 2013).

\subsection{Interactive Whiteboards (IWB) in the Classrooms}

One form of technology that can be used as a pedagogical tool is the IWB. Research proved that IWBs are a greatly interactive presentation tool in a way that teachers and students can control and manipulate programs by using a touch sensitive large screen (Marzano, 2009; Digregorio\& Sobel- Lojeski, 20092010). They make student excited, make the instruction enhanced, and finally make the school climate changed (Harper, Dzaldov, \& Booth, 2011; Harden-Thew, 2012). There is a noticeable increase in the energy, enthusiasm and activity levels of the students and teachers when using the IWBs that make the classrooms very active (Northcote et al., 2010; Hall \& Higgins, 2005; Higgins, 2010; Harden-Thew, 2012). Learners are interested in using IWBs since they can interestingly express theirnew knowledge and media (Mercer, Hennessy, \& Warwick, 2010; Littleton, 2010; Maher, 2012; Yudt\& Columba, 2011; Türel\& Johnson, 2012).

Hall and Higgins (2005) argued that "the purpose of using IWBs in the classroom is to enable access to and use of digital resources for the benefit of the whole class while preserving the role of the teacher in guiding and monitoring learning" (p. 104). The British Educational Communications and Technology Agency (BECTA; 2003) pointed out that using IWBs during instruction provides more space for teachers and the whole class to get through digital resources at the same time. Using IWBs in classrooms, the instructor has a role of facilitator to play through monitoring and guiding learning. During instruction, the potential advantages of using IWBs are that teachers can teach concepts, stream videos, graphics, combine text, audio, and video through manipulation, practice handwriting within the large screen (BECTA, 2003). Learners in general like IWBs due to the variety of activities provided and available resources in IWBs. Thus, they enjoy the multimedia capabilities in which IWBs offer, particularly the audio and video features. There are other IWB characteristics such as the sounds, color, 
movement, the manipulation of objects, and video clips on the touch large board. Learners find the lessons more enjoyable and fun while using IWBs (Hall \& Higgins, 2005). However, there are some disadvantages regarding the use of IWBs. For example, teachers lack the experience of how to use IWBs in an effective way (Hall \& Higgins, 2005).

Kitson, Fletcher, and Kearney (2007) investigated, regarding the area of multiliteracies, the effects of the implementation of IWBs on teacher practice. The study was in collaboration between a teacher and a team of university-based researchers and the use of an ethnographic approach in order to gain new insight into the demands of teaching with new technologies. The study examined the gap between theory and practice concerning the use of technology to teach literacy. Data were collected from field notes, observations, reflective journal entries, videotapes, and cultural artifacts. They were analyzed to interpret ways in which teachers created meaning of multiliterate practices in the classroom while reading a multimodal text on an IWB. The data indicated that the teachers ${ }^{\text {ee }}$ practices focused mainly on traditional print-based modes of communication. The findings indicated that there was a discrepancy between the teachers ${ }^{\text {ee }}$ stated and acted beliefs concerning the use of IWBs inside classrooms.

Furthermore, Lopez (2010) investigated the use of IWBs in the classroom. Unlike Kitson "s et al (2007) study, Lopez se (2010) study was based on quantitative approach. It evaluated the Round Rock (Texas), Independent School Districtes (ISD) and Digital Learning Classroom project that was initiative with using IWBs to boost English Language Learners ${ }^{\text {ee }}$ performance. The researcher examined whether the use of IWBs had an impact on the math and reading achievement of ELL students. This was done to possibly eliminate the achievement gap between general education students and ELL students and in the third and fifth grade.

Smith et al. (2005) conducted an intensive review concerning the introduction of interactive whiteboards as an instructional tool in schools. In their study, the evaluation focused mainly on the effect of IWB in class interaction, teacher perceptions and on students ${ }^{\text {ee }}$ achievement, attitudes and progress. It should be noted that two categories were discussed and analyzed. They included the use of the IWB as a tool to enhance learning and as a tool to encourage teaching. The researchers pointed out teachers found that the IWB as being a flexible and versatile instructional tool used in teaching among under different settings and different age groups. The IWB allowed the use of multimedia such as video, sound, and images. It also allowed the interactive features such as real time movement in rotating an object or interactive games. Furthermore, the most incredible findings was that it eliminated disruption, improved visibility and reduced repetitions in a way that what might be written could be saved and reviewed again. Thus, the use of IWB could lead to motivation.

When using the IWB, the learners are motivated by making the lesson more enjoyable and interesting. This results in improving the attention and behavior. Due to the multi-sensory input, each type of learning styles makes a difference. However, there are many problems connected with using the IWB. For example, Smith et al. (2005) stated that some of the common problems are mainly associated with training, practicalities, and support. To be more specific, inadequate IT supports and lack of trainings can hamper, frustrate and impede teachers from acting in a proper way. Other problems included the day light reflection on the IWB, dust on the projector or the board itself, and the position of the IWB within a classroom. The shadow of the user on the IWB sometimes can hamper learning process in a way that passively affects learning.

Though the UK government allocated $£ 50$ million to purchase IWBs for primary and secondary classrooms since research on this form of technology was still in the beginning, researchers chose to shed light on the use of the IWB inside classrooms (Armstrong et al., 2005). It is important to note that there was that little research done regarding the use of the IWB from the perspective of teaching and learning. The data collection involved digital recordings of three one-hour lessons and four teachers who participated in the study. There were also interviews with the teachers together with two focus groups. This focus group included six students in each class (Armstrong et al., 2005). The researchers found that support and in-service training are crucial for teachers to appropriately use the IWB in orderto select 
acceptable software. The findings showed that the IWB had an effective use in promoting quality interactions between students and their teacher.

Gillen, Littleton, Twiner, Staarman, and Mercer (2008) explored a case study regarding the use of the IWB and showed how it supported the teaching of primary science. The purpose of the case study developed was to investigate how the IWB was used to teach two science themes within four lessons. Additionally, it examined how the teacher creates continuity in student learning as well as engaging students in activities to consolidate their realization. Their research design was an analytic case study that relied on qualitative data to measure the effectiveness of the IWB as well as engagement of students. The findings of the case study investigated proposed that the IWB is a fruitful tool that facilitates interactions with multiple modes of representation. The researchers stated that the objectives of the lesson could have been met using multiple modes of representation without the use of the IWB. However, it would have been time-consuming to use such complicated combinations allowed by the technology. To sum up, IWBs can be used as a pedagogical tool that causes benefits for student learning due to the ability to manipulate and present multiple modes of information.

\section{Conclusion}

This description and analysis of the interactive whiteboard presented in the foreign language classrooms has offered a remarkable impression in which the Interactive whiteboard is considered a very innovative and powerful tool that provides support for language acquisition and fruitful learning engagement. This kind of technology offers a bridge that allows the skill of using the IWB without breaking any communication between the teacher and his/her students. It encourages interaction and participation among learners. Moreover, this pedagogical tool may enhance new kinds of learning processes that encompasses various learning styles. Training courses should be well prepared and organized to access more resources without any hindrance. This let teachers gain more awareness to the use of such technology inside their classrooms. More studies could be qualitatively conducted to spot the realistic part occurring among learners. Interviews or classroom observation could provide more data concerning the pros and cons of the use of the interactive whiteboard (IWB).

\section{References}

Abraham, R. \&Liou, H. (1991). Interaction generated by three computer programs: Analysis of functions of spoken language. In: DUNKEL P. (1991). Computer-Assisted Language Learning and Testing. Research, Issues and Practice (pp. 133-154). NewYork: Newbury House/HarperCollins.

Al-Saleem, B. (2013). The interactive whiteboard in English as a foreign language (EFL) classroom. European Scientific Journal, 8(3), 126-134.

Allen, A. (2010). Interactive Whiteboard Evaluation. Retrieved February 23, 2016, from www.mirandanet.ac.uk/pubs/SMARTBoard.htm.

Bacon, D. (2011). The interactive whiteboard as a force for pedagogic change.

Information Technology in Education Journal, 15-18.

Barone, D., \& Wright, T. (2008). Literacy instruction with digital and media technologies. Reading Teacher, 62(4), 292-302.

Barrow, L., Markman, L., \& Rouse, C. (2009). Technology's edge: The educational benefits of computer-aided instruction. American Economic Journal: Economic Policy, American Economic Association, 1(1), 52-74. Retrieved from http://www.nber.org/papers/w14240.pdf

Beeland, J. (2002). Student Engagement, Visual Learning and Technology: Can Interactive Whiteboards Help? $\quad$ Retrieved February $\quad 1 s t, \quad 2016, \quad$ from http://chiron.valdosta.edu/are/Artmanscrpt/vol1no1/beeland_am.pdf. 
Belal, A. (2011). Students' perceptions of computer assisted learning: An empirical study. International Journal of Management in Education, 5(1), 63-78.

Burnett, C. (2010). Technology and literacy in early childhood educational settings: A review of research. Journal of Early Childhood Literacy, 10(3), 247-270.

Chambers, B., Slavin, R., \& Madden, N. (2008). Technology infusion in Success for All: Reading outcomes for first graders. Elementary School Journal, 109(1), 1-15. Retrieved from http://dx.doi.org/10.1086/592364

Chapelle, J. (2003). How Is the Interactive Whiteboard Being used in Primary School? Becta Research Bursary. Retrieved Dec. 12, 2011, from www.virtuallearning.org.uk/whiteboards/IFS_interactive whiteboards_in_the primary _ school.pdf.

Cheung, A. \&Slavin, R. (2011). The effectiveness of education technology for enhancing reading achievement: A meta-analysis. Best Evidence Encyclopedia. Retrieved

fromhttp://www.bestevidence.org/word/tech_read_Feb_24_2011.pdf

Digregorio, P. \& Sobel-Lojeski, K. (2009-2010). The effects of interactive whiteboards (IWBs) on student performance and learning: A literature review. Journal of Educational Technology Systems, 38(3), 255-312.

Englert, C., Zhao, Y., Collings, N., \&Romig, N. (2005). Learning to read words: The effects of Internetbased software on the improvement of reading performance. Remedial and Special Education, 26(6), 357-371.

Ertmer, P. (2005). Teacher pedagogical beliefs: The final frontier in our quest for technology integration?

Educational Technology Research and Development, 53 (4), 25-39.

Hall, I. \& Higgins, S. (2005). Primary school students ${ }^{\text {ee }}$ perceptions of IWBs. Journal of Computer Assisted Learning, $\quad 21$, 102-117.Retrieved from

http://faculty.ksu.edu.sa/Alhassan/2503/primery\%20students\%20perception\%20of\%20whiteboards\%20

2005.pdfHarden-Thew, K. (2012). Transition to school, success, and an interactive whiteboard. Practically Primary, 17(1), 34-36. Retrieved from http://findarticles.com/p/articles/mi_6953/is_1_17/ai_n58569338/

Harper, J., Dzaldov, B. \& Booth, D. (2011). Literacy smarts: Simple classroom stratetgies for using interactive whiteboards to engage students. Markham, ON: Pembroke Publishers.

Higgins, S. (2010). The impact of interactive whiteboards on classroom interaction and learning in primary schools in the UK. In M. Thomas \& E. C. Schmid (Eds.), Interactive whiteboards for education: Theory, research and practice (pp. 86- 101). Hershey, PA: IGI Global.

Geske, A. \&Ozola, A. (2009). Different influence of contextual educational factors on boys ${ }^{\text {ee }}$ and girls ${ }^{\text {ee }}$ reading achievement. US-China Education Review, 6(4), 38-44.

http://www.eric.ed.gov/PDFS/ED505734.pdf

Retrieved from

Gillen, J., Littleton, K., Twiner, A., Staarman, J., \& Mercer, N. (2008). Using the interactive whiteboard to resource continuity and support multimodal teaching in a primary science classroom. Journal of Computer Assisted Learning, 24(4), 348-358

Kendeou, P., van den Broek, P., White, M. J., \& Lynch, J. (2009). Predicting reading comprehension in early elementary school: The independent contributions of oral language and decoding skills. Journal of Educational Psychology, 101(4), 765- 778.

Kitson, L., Fletcher, M., \& Kearney, J. (2007). Continuity and change in literacy practices: A move towards multiliteracies. Journal of Classroom Interaction, 41(2), 29-41.

Lenhard, W., Baier, H., Endlich, D., Schneider, W., \& Hoffmann, J. (2011). Rethinking strategy instruction: direct reading strategy instruction versus computer-based guided practice. Journal of Research in Reading, 35(3).

Littleton, K. (2010). Research into teaching with whole-class interactive technologies: 
Emergent themes.

Technology, Pedagogy \& Education, 19(2), 285-292.

Lopez, O. (2010). The digital learning classroom: Improving English Language Learnerse academic success in mathematics and reading using interactive whiteboard technology. Computers \& Education, 54(1), 901-915.

Maher, D. (2012). Teaching literacy in primary schools using an interactive whole-class technology: facilitating student-to-student whole-class dialogic interactions. Technology, Pedagogy and Education, 21(1), 137-152.

Marzano, R. (2009). Teaching with interactive white boards. Educational Leadership, 80-82. Retrieved from $\quad$ http://www.ascd.org/publications/educationalleadership/nov09/vol67/num03/Teaching-withInteractive-Whiteboards.aspx

Mercer, N., Hennessy, S., \& Warwick, P. (2010). Using interactive whiteboards to orchestrate classroom dialogue.

Technology, Pedagogy and Education, 9(2), 195- 209.

Northcote, M., Mildenhall, P., Marshall, L., \& Swan, P. (2010). Interactive whiteboards: Interactive or just whiteboards? Australasian Journal of Educational Technology, 26(4), 494-510. Retrieved from http://www.ascilite.org.au/ajet/ajet26/northcote.pdf

Pennington. M. (1996). The power of CALL. Athelstan Publications. Houston, Texas 77005. USA

Reed, S. (2001). Integrating an Interactive Whiteboard into the Language Classroom. Retrieved February12, 2016, from http://ferl.becta.org.uk/ display. cfm?resid=1569\&printable=1

Smith, H. J., Higgins, S., Wall, K \& Miller, J. (2005). Interactive whiteboards: boon or bandwagon? A critical review of the literature. Journal of Computer Assisted Learning 21, 91-101.

The British Educational Communications and Technology Agency [BECTA]. 2003. What the research says about interactive whiteboards. Coventry, UK: Author.

Türel, Y. \& Johnson, T. (2012). Teachers ${ }^{\text {ee }}$ belief and use of interactive whiteboards for teaching and learning. Journal of Educational Technology \& Society, 15(1), 381-394. Retrieved from http://www.ifets.info/journals/15_1+32.pdf.

U. S. Department of Education [USDOE] (2005). An Invitation to Building Choice.org: Raising achievement through public school choice. Innovations in Education Resource. Retrieved February 12, 2016 fromhttp://proxygsu-satl.galileo.usg.edu

Yudt, K., \& Columba, L. (2011). Interactive whiteboards: A tool for enhancing teaching and learning. Journal of Technology Integration in the Classroom, 3(2), 17-22. 